\title{
The Book of Genesis: A Biography, by Ronald Hendel
}

Lives of Great Religious Books | Princeton and Oxford: Princeton University Press, 20I3 | xii + 287 pages | ISBN: 978-0-69II 4 O I 2-4 (hardback) $\$ 24.95$

The Book of Genesis: A Biography appears in the Princeton University Series, Lives of Great Religious Books

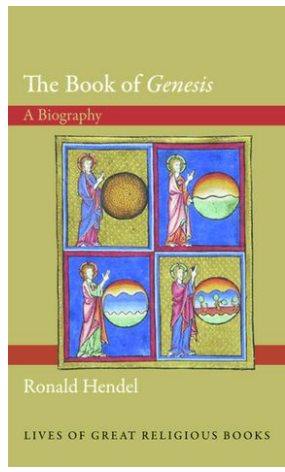
alongside the stories of other great works such as The Dead Sea Scrolls (John J. Collins) and Augustine's Confessions (Garry Wills). This is a new series of short volumes that aims to recount the complex and fascinating histories of important religious texts from around the world.

The reason for the inclusion of Genesis in this series is flagged up right at the start on the volume's cover. During its 2,500-year life, the book of Genesis has been the keystone to almost every important claim about reality, humanity, and God in Judaism and Christianity and continues to play a central role in debates about science, politics, and human rights. Hendel aims to trace in this volume how Genesis has shaped views of reality and how changing views of reality have shaped interpretations of Genesis. Literal and figurative readings have long competed with each other. Hendel demonstrates how Luther's criticism of traditional figurative accounts of Genesis undermined the Catholic Church; how Galileo made the radical argument that the cosmology of Genesis wasn't scientific evidence; and how Spinoza made the really radical argument that the scientific method should be applied to Genesis itself. Many high points of Western thought and art have taken the form of encounters with Genesis from Paul and Augustine to Charles Darwin, Emily Dickinson, and Franz Kafka.

Hendel does not follow the standard reception-history approach in dealing with the impact of Genesis across the centuries nor does he deal with its many cultural interpretations and manifestations. Although he does deal briefly towards the end of the volume with the literature of Dickinson and Kafka, he focusses rather on the philosophical, hermeneutical, and theological aspects of the history of the book's interpretation. He focusses on the "life" of Genesis and its "afterlife," which he defines as "its original meanings and its effects on later generations." Through its transformation over time, the text takes on new layers of sense, some of which may have been unthink- 
able previously. The book becomes a historical agent, which enters into new religious and political configurations.

Quite rightly Hendel states that his plotting of the biography of Genesis will emphasise certain bits and overlook others, but nevertheless has the advantage of making a coherent story that demonstrates the consistent appeal of the book (Introduction, I I). He thus structures his volume accordingly: in chapter I ("The Genesis of Genesis") he emphasises the figural dual reality in which this world is a flawed version of a more perfect world and Genesis is a more perfect version of a more perfect text (ch. 2: "The Rise of the Figural Sense"). The hidden world which Genesis reveals has two modalities: one is in future time at the End of Days (ch. 3: "Apocalyptic Secrets") and the other is in metaphysical space, the Higher World (ch. 4: "Platonic Worlds"). People do things with Genesis in order to influence and change reality. In the early modern period (between I 200 and I600) people in the West began to return to a single world, in which our lives are bonded spatially by the earth and temporally by death. The foundations of the figural worlds were undermined (ch. 5: "Between the Figure and the Real") and so people began to read Genesis in its plain or realistic sense, not as a cipher about other worlds. The real world of Genesis does not map on to the modern scientific view of the world (ch. 6: "Genesis and Science"). Its philosophical concepts do not map on to modern concepts either. Yet it remains a part of our moral, religious and political lives (ch. 7: "Modern Times"). Despite the fact that it is mostly myth and legend, in modern times Genesis is still good to think about and to do things with.

Hendel stresses in several places throughout his volume that Genesis is a book that people always felt that "they could do things with." This is a really good phrase to use and sums up the range and variety of interpretative contexts that Genesis could lend itself to over the centuries. Hendel chooses a number of interpretive contexts that provide a varied and representative number of examples of the appeal of Genesis to many diverse minds. However, given his interpretative focus (which is, of course, the real appeal of the book), I found his chapter I to be the least interesting. Here, Hendel attempts to deal with the literary origins of the book and leans heavily on Wellhausen's Documentary Hypothesis (J, E, D, P) in seeking to determine the oldest part of Genesis (which he states categorically on page 15 to be the so-called Blessing of Jacob in Gen 49). I feel it would have been in more keeping with the aim of the book if he had emphasised more the literary qualities of Genesis (à la Robert Alter) and drew more attention to its strik- 
ing and original themes rather than trying to determine its precise historical literary authorship. This would have prepared the way better for his subsequent chapters. This said, apart from chapter I, the rest of the chapters all provide the reader with copious and detailed information about the interpretative history of the book.

In chapter 2, Hendel uses the four assumptions of traditional biblical interpretation suggested by James Kugel in The Bible as It Was (Harvard University Press, 1997) - that the Bible is cryptic, relevant, perfect, and divineand claims that these four assumptions "undergird all the different forms of early biblical interpretation as well as the views of reality that came to prevail in this era." A cryptic text has coded or hidden meanings (for example, the life of Enoch in Gen 5:2I-24) which it is the task of interpreters to uncover. By relevant, Hendel implies the question: how can lists of people and places in Genesis be relevant to the present? If Genesis is the perfect "Torah of God," then how can there be contradictions within it? Connected to all the assumptions is the global assumption that Genesis is divine speech-either authorised or authored by God himself.

In chapter 3 , Hendel deals with apocalyptic interpretations of Genesis. "For over two thousand years," he states (64), "the life of Genesis has been shaped by the belief that it is a repository of apocalyptic secrets." Particularly interesting in this regard is his discussion of apocalyptic interpretations of the character of Adam in his section (70-78) which he entitles "The Glory of Adam" after a phrase taken from one of the Dead Sea Scrolls.

In chapter 4, Hendel explores how the interpretation of Genesis has been shaped by Platonic ideas. Particularly interesting in this regard is his discussion of "the Greek Genesis" (88-90) where he draws attention to the fact that the Septuagint is not simply a Greek translation of the Hebrew of Genesis but a translation that allows Genesis to take on a "Greek colour." Since the Septuagint became the standard Scripture for Greek-speaking Jews and most Christians, including all the writers of the New Testament, Genesis described for them and their descendants a Platonic world. It was much more than a simple translation. On pages 98-I02, in the same chapter, Hendel also draws attention to the attraction of Genesis in the early Christian period where the so-called Gnostic Genesis offers a "Platonizing reimagining of Genesis." There are also other outstanding and original discussions in this section of the book: for example, the intense interest in the hidden and symbolic meanings of the texts, evident in the works of Augustine which Hendel deals with in detail in chapter 5 . 
In chapter 6, Hendel introduces and summarises many of the disputes surrounding the clashes that began to emerge from the seventeenth century between scientific discoveries and literal readings of the early chapters of Genesis. For example, from page I 47, Hendel presents a clear and concise overview of several of the controversies that centred around cosmology.

In chapter 7 , in his chapter on modern times, Hendel focuses on slavery and emancipation. He shows how the most crucial biblical text for the proslavery position was the story of Noah's drunkenness in Gen 9. He offers a most interesting and detailed (and to many readers this will be totally new) discussion of this text and its importance in the context of the American civil war. Although Hendel offers a short section on the "second sex" (2047), I would have liked to have seen a more detailed section on how feminist interpreters deal with the many texts in Genesis that portray the roles given to women in the patriarchal narratives.

To describe this book as a "short volume" is quite misleading. It contains a wealth of information, usefully structured into thematic chapters and offers the reader aspects of the interpretative history of Genesis that she or he will not find in standard biblical commentaries_or indeed in books and articles that deal with the reception history of Genesis. In addition the book will appeal to those with either a detailed or very sparse knowledge of the history of a text that clearly holds an unending fascination in every age.

Martin O'Kane

University of Wales

Trinity Saint David 